Revista Brasil. Bot., V.31, n.2, p.237-244, abr.-jun. 2008

\title{
Reproductive phenology of Melocactus (Cactaceae) species from Chapada Diamantina, Bahia, Brazil ${ }^{1}$
}

\author{
ROSINEIDE BRAZ SANTOS FONSECA ${ }^{2,4}$, LIGIA SILVEIRA FUNCH² and EDUARDO LEITE BORBA ${ }^{3}$
}

(received: May 03, 2007; accepted: April 24, 2008)

\begin{abstract}
Reproductive phenology of Melocactus (Cactaceae) species from Chapada Diamantina, Bahia, Brazil). This paper discusses the phenological strategies of Melocactus glaucescens Buining \& Brederoo, M. paucispinus G. Heimen \& R. Paul, M. ernestii Vaupel and M. xalbicephalus Buining \& Brederoo, species from Chapada Diamantina, northeastern Brazil. Melocactus glaucescens, M. ernestii and M. ×albicephalus occur sympatrically in an area of "caatinga"/"cerrado" vegetation, and M. paucispinus in an area of "cerrado"/"campo rupestre". The superposition of flowering in these sympatric taxa was compared and analyzed. The phenology of M. paucispinus was correlated with both abiotic and biotic factors. Flowering of M. glaucescens and M. ×albicephalus were observed to be continuous (though with moderate peaks of activity), while fruiting was sub-annual. Melocactus ernestii exhibited an annual pattern of both flowering and fruiting; while in M. paucispinus the same patterns were sub-annual. These sympatric taxa showed $40 \%$ overlap of flowering periods, reaching to more than $50 \%$ in paired combinations of taxa, considering both the number of specimens flowering, as well as the quantity of resources being offered. Available information indicates that these taxa share pollinators, but phenological data rejects the hypothesis of shared pollinators and supports the hypothesis of hybridization in the study area. Rainfall was negatively correlated with flowering in M. paucispinus, but positively correlated with fruiting. Flowering of $M$. paucispinus in dry periods of the year avoids that erect flowers positioned in terminal cephalium, exposed in open areas of the vegetation, be damaged for the rains, while fruiting in rainy periods can be favorable to the dispersion and germination of this species.
\end{abstract}

Key words - Cactaceae, hybridization, Melocactus, phenology, reproductive biology

RESUMO - (Fenologia reprodutiva de espécies de Melocactus (Cactaceae) da Chapada Diamantina, Bahia, Brasil). Este trabalho discute as estratégias fenológicas de Melocactus glaucescens Buining \& Brederoo, M. paucispinus G. Heimen \& R. Paul, M. ernestii Vaupel e $M$. ×albicephalus Buining \& Brederoo, espécies da Chapada Diamantina, Nordeste do Brasil. M. glaucescens, M. ernestii e $M$. ×albicephalus ocorrem simpatricamente em uma área de caatinga/cerrado e $M$. paucispinus em uma área de cerrado/campo rupestre. A fenologia dos táxons simpátricos foi comparada e analisada quanto à sobreposição, enquanto a fenologia de M. paucispinus foi correlacionada com fatores abióticos e bióticos. A floração de M. glaucescens e $M$. $\times$ albicephalus apresentou um padrão contínuo, porém com picos moderados de atividade, enquanto a frutificação foi subanual. A floração e a frutificação de M. ernestii exibiram padrão anual; em M. paucispinus, a floração e a frutificação tiveram padrão subanual. Os táxons simpátricos apresentaram juntos mais de $40 \%$ de sobreposição de floração, e mais de $50 \%$ em combinações aos pares, considerando tanto o número de indivíduos em floração quanto à quantidade de recurso ofertado. Informações disponíveis indicam que esses táxons compartilham polinizadores. Os dados fenológicos encontrados rejeitam a hipótese do polinizador compartilhado e sustentam a hipótese corrente de hibridação na área estudada. Foi encontrada correlação negativa entre a pluviometria e a floração de $M$. paucispinus e positiva com a frutificação. A floração de $M$. paucispinus em períodos secos do ano evita que as flores eretas posicionadas em cefálios terminais, expostos em áreas abertas da vegetação, sejam danificadas pelas chuvas, enquanto a frutificação em períodos chuvosos pode ser favorável à dispersão e germinação desta espécie.

Palavras-chave - Biologia reprodutiva, Cactaceae, fenologia, hibridação, Melocactus

\section{Introduction}

The study of phenology is concerned with repetitive biological events and their causes in relation to abiotic

1. Part of the Masters dissertation of the first author, Graduate Program in Botany, Universidade Estadual de Feira de Santana, Feira de Santana, Bahia, Brazil.

2. Universidade Estadual de Feira de Santana, Departamento de Ciências Biológicas, Rodovia BR 116, km 03, 44031-460 Feira de Santana, Bahia, Brazil.

3. Universidade Federal de Minas Gerais, Instituto de Ciências Biológicas, Departamento de Botânica, Av. Antônio Carlos, 6627, 31270-901 Belo Horizonte, Minas Gerais, Brazil.

4._Corresponding author: rosineide_braz@hotmail.com and biotic factors, endogenous and phylogenetic restrictions within a population and/or a community, and the interactions between them (Wright \& Calderon 1995).

Phenological studies can aid our understanding of growth strategies, regeneration, and reproduction of plants under different environmental conditions, the temporal and spatial organization of resources within a species or among groups of species that are closely related or that have similar morphologies or ecological requirements, as well as the biological interactions (competition, herbivory, pollination, and dispersion) important to reproductive success (Frankie et al. 1974, Lieth 1974, Wright \& Calderon 1995). 
A variety of causal factors have been cited for the temporal nature of the phenological events that can result in a greater or lesser degree of overlap of flowering and/ or fruiting among plant species. These include abiotic factors (Sarmiento \& Monastério 1983, Reich \& Borchert 1984, Wright \& van Schaik 1994), biotic factors (Gentry 1974, Stiles 1977, Ashton et al. 1988), or phylogenetic restrictions (Kochmer \& Handel 1986, Johnson 1992, Ollerton \& Lack 1992, Wright \& Calderon 1995).

In tropical regions, especially in those areas exposed to periodic droughts (such as the "cerrado" and "caatinga"), plant water relations have received considerable attention. Seasonal rainfall has often been cited as the determinant climatic factor in these areas (Reich 1994, Williams-Linera \& Meave 2002), and has thus been associated with the seasonality of phenological phenomena - principally in plants having shallow root systems (and unable to use deep soil water) and non-succulents (Nobel 1977, Sarmiento \& Monastério 1983, Bertiller et al. 1991). Petit (2001) examined the responses of three sympatric columnar cacti to rainfall on the semi-arid island of Curaçao, and determined that each species responded differently to limitations presented by seasonal water shortages. These results are similar to those reported by Pavón \& Briones (2001) for perennial shrubs in Mexico.

The fact that species show different responses to environmental factors according to their life form may partially explain the divergence or convergence of phenological patterns in plants subjected to identical environmental conditions. The divergent phenological patterns seen among plants with similar growth habits, as in the study by Petit (2001), however, may be explained by selective biotic pressures. Among the many possible selective factors, pollination agents have received the greatest attention. Variations in flowering time among groups of plants that share the same pollinators may be explained by the hypothesis that the temporal spacing of flowering minimizes pollinator competition and maximizes pollination efficiency undertaken by shared agents (Gentry 1974, Stiles 1977 , Ashton et al. 1988). Flowering displacement that avoids overlapping among sympatric species is an important pre-zygotic isolation mechanism, preventing interspecific hybridization and maintaining species integrity (Stace 1992, Levin 2000). This is particularly important among species demonstrating very similar flower morphology and that share pollinators, as observed in the genus Melocactus (Locatelli \& Machado 1999, Nassar \& Ramírez 2004, Colaço et al. 2006). Phenological research at the population level in tropical regions has been expanding, although few references are found for the genus Melocactus. Phenological data is available for flowering in M. zehntneri (Britton \& Rose) Luetzelb. (Locatelli \& Machado 1999) and M. curvispinus Pfeiffer (Nassar \& Ramírez 2004).

Among the species examined in the present study, M. paucispinus G. Heimen \& R. Paul and Melocactus glaucescens Buining \& Brederoo are endemic to the state of Bahia, northeastern Brazil, and are listed as threatened in the IUCN Red List (Taylor 1991, Oldfield 1997, Taylor 2000, Taylor \& Zappi 2004). Melocactus paucispinus is distributed generally in small populations throughout the Chapada Diamantina, in the municipalities of Seabra, Morro do Chapéu, Umburanas, Rio de Contas, and Abaíra (Machado 1999, Machado \& Charles 2004, Taylor \& Zappi 2004).

Melocactus glaucescens is restricted to the municipality of Morro do Chapéu, where only four populations with reduced numbers of individuals are known to occur (Taylor \& Zappi 2004). The type population is much degraded, showing evidence of hybridization with $M$. ernestii Vaupel. This hybrid is identified as $M$. xalbicephalus Buining \& Brederoo (Taylor 1991, 2000, Taylor \& Zappi 2004).

Hybridization is quite frequent in plants (Stace 1992) and although it can be very important from an evolutionary point of view, it can impoverish biodiversity by allowing the fusion of two different species via interspecific gene flow, and may promote species extinction by inhibiting their population growth, hampering effective reproduction, competitive status, and ecological interactions, which may lead to the complete lost of populations through formation of hybrid swarms (Levin et al. 1996, Rhymer \& Simberloff 1996).

In light of the importance of phenological studies to our understanding of population dynamics, the present work sought to examine the phenological strategies of Melocactus glaucescens and M. paucispinus and determine the phenological cycles of $M$. ernestii as well as of the hybrid $M$. ×albicephalus by comparing the phenologies of these taxa and determining the degree of temporal overlap of their flowering and fruiting. Additionally, we sought to relate the phenological patterns of M. paucispinus to environmental conditions (temperature, humidity, and rainfall). This approach was not possible with $M$. glaucescens, $M$. ernestii, and M. ×albicephalus, however, as meteorological data is not available for the area in which they occur.

Additionally, we discuss the fruiting strategies of M. paucispinus, focusing on dispersal agents. 


\section{Materials and methods}

Study areas and species - The populations of Melocactus glaucescens, M. ernestii, and the hybrid M. ×albicephalus examined here are located between $11^{\circ} 29^{\prime} 19.0^{\prime \prime}-11^{\circ} 29$ ' $25.5^{\prime \prime} \mathrm{S}$ and $41^{\circ} 20^{\prime} 11.1^{\prime \prime}-41^{\circ} 20^{\prime} 31.3^{\prime \prime} \mathrm{W}$, and between $500-910 \mathrm{~m}$ a.s.1., within the boundaries of the "Parque Estadual do Morro do Chapéu", in the municipality of Morro do Chapéu, Bahia State, Brazil. Melocactus glaucescens grows on sandy soils in open areas, M. ernestii is restricted to small crevices in exposed rock surfaces, while plants of $M$. ×albicephalus can be found growing in rock crevices, or in areas with sandy soil or gravel. The local vegetation represents an area of transition between the dry "caatinga" vegetation and "cerrado" (savanna) (CPRM 1995). The local climate is classified as high altitude tropical with hot summers. The mean temperature of the coldest month (July) is less than $18{ }^{\circ} \mathrm{C}$, and the mean temperature of the warmest month (January) is above $22{ }^{\circ} \mathrm{C}$. The estimated mean annual average temperature is approximately $22{ }^{\circ} \mathrm{C}$, while the mean annual rainfall is less than $700 \mathrm{~mm}$ (CPRM 1995), but the study areas where the populations of $M$. glaucescens, M. ernestii, and $M$. ×albicephalus are found are too distant from any meteorological station to accurately determine their environmental conditions.

The population of Melocactus paucispinus is located at $11^{\circ} 33$ ' $52^{\prime \prime} \mathrm{S}$ and $41^{\circ} 10^{\prime} 37^{\prime} \mathrm{W}$, at approximately $1104 \mathrm{~m}$ a.s.1., in the central portion of the municipality of Morro do Chapéu, Bahia State, Brazil. M. paucispinus grows on sandy soils in open in a phyto-ecological contact zone where the "cerrado" vegetation merges and forms mosaics with "campo rupestre" formations (CPRM 1995) with many small trees, shrubs, and sparse collimate cacti. The area has a predominately tropical altitudinal climate with mild summers. The mean temperature of the coldest month (July) falls below $18{ }^{\circ} \mathrm{C}$, while the mean temperature for the warmest month (January) is less than $22^{\circ} \mathrm{C}$ (CPRM 1995). The mean weighted annual temperature is $19.7^{\circ} \mathrm{C}$, and the mean annual rainfall is approximately $750 \mathrm{~mm}$ (DNMET 1992). Climatic data was obtained from Morro do Chapéu meteorological station located $3 \mathrm{~km}$ east of the study site.

The rainfall patterns in the two study areas are typical of semi-arid regions. The rainy season extends from November until April, with December generally having the most precipitation (usually concentrated in 10 to 13 days). The dry season extends from May until October, when rainfall is less generally than $60 \mathrm{~mm}$. Although rainfall is sparse during this period, the total number of rainy days may be greater than in the rainy season, often totaling 15 days in June and July (DNMET 1992).

Phenology - Phenological observations of randomly chosen individuals of the different species of Melocactus were undertaken on a monthly basis during the period from August 2002 to July 2003. Seventy individuals M. glaucescens with cephalia were marked (more than $85 \%$ of the population),
50 individuals of $M$. paucispinus (approximately $50 \%$ of the population), and 20 individuals of both $M$. ernestii and M. ×albicephalus (essentially the entire population). The marking of the plants was assisted by specialists in Cactaceae taxonomy, Dr Nigel P. Taylor (Royal Botanic Gardens, Kew) and Marlon C. Machado (Institut für Systematische Botanik, Universität Zürich).

Observations were carried out in the afternoon (during anthesis), noting the following parameters: presence of flowering (open flowers) or fruiting (mature fruits, ready to be dispersed); the number of individuals in each phenophase; number of open flowers on each individual (daily offering); number of mature fruits not available (protruding less than $0.3 \mathrm{~cm}$ from the cephalium - emerging fruits) and available (protruding more than $0.3 \mathrm{~cm}$ from the cephalium - extruded fruits, hanging or fallen on to the cephalium, or to the ground) per individual, adapting the criteria adopted by Figueira et al. (1994). We also recorded the time of flower bud appearance on the surface of the cephalium $(n=20)$, and the time of anthesis of 20 flowers. For these measurements, 30 adult individuals of each species were examined every half hour, from 08:00 to 15:00 hours during three to four days (to total 20 observations).

Phenological patterns were classified according to the frequency and duration of the flowering and fruiting stages, following Newstrom et al. (1994). The Spearman Correlation $\left(r_{\mathrm{s}}\right)$ was used to relate flowering and fruiting in $M$. paucispinus with abiotic factors (temperature, humidity, and rainfall). The Krebs (1989) formula was used to calculate the degree of overlap of flowering (number of individuals with flowers, and number of flowers presented) of $M$. glaucescens, $M$. ernestii, and $M$. ×albicephalus (considering the three taxa and all combinations of pairs), as well as the degree of overlap of fruiting (number of individuals with fruits, and number of fruits exhibited $): \mathrm{P}_{j k}=\left[\sum^{n}\left(\right.\right.$ minimum $\left.\left.\mathrm{P}_{i j}, \mathrm{P}_{i k}\right)\right] 100$, where $\mathrm{P}_{j k}=$ Percentage of flowering (or fruiting) overlap among the species $j$ and $k ; \mathrm{P}_{i j}, \mathrm{P}_{i k}=$ proportion of the resource $i$ produced in each month in relation to the total resource offered by the species $j$ and $k$ during the study period; $n=$ total number of sampling dates.

\section{Results}

The flower buds of Melocactus glaucescens and M. paucispinus appear on the surface of the cephalium on the day of anthesis, generally between 09:00 and 10:00 hours, although they can sometimes appear only a few minutes ( $\mathrm{ca} .30$ ) before anthesis. The buds open only once (one-day flowers), between 13:00 and 14:00, and then begin to wither starting at 19:00. The daily offering of flowers per individual varied from one to 12 for both species.

Melocactus glaucescens produced flowers during almost the whole year, with only small interruptions (figure 1A). The number of flowering individuals indicated 
a continuous pattern according to Newstrom et al. (1994), although the absolute quantity of floral resources offered on a monthly basis showed moderate peaks (figure 1B). Fruiting in M. glaucescens was subannual, with two cycles per year of intermediate duration, with episodes concentrated in one month (figures 1A, B).

Flowering and fruiting of $M$. ernestii was annual and of intermediate duration, considering the number of flowering individuals as well as the quantity of resources offered (figures 1C, D). Flowering of M. ×albicephalus was extended, with only short interruptions. Peaks of activity were only evident when the quantity of floral resources offered was considered. Fruiting showed an intense period during one month, followed by a longer, but less intense episode (figures $1 \mathrm{E}, \mathrm{F}$ ).
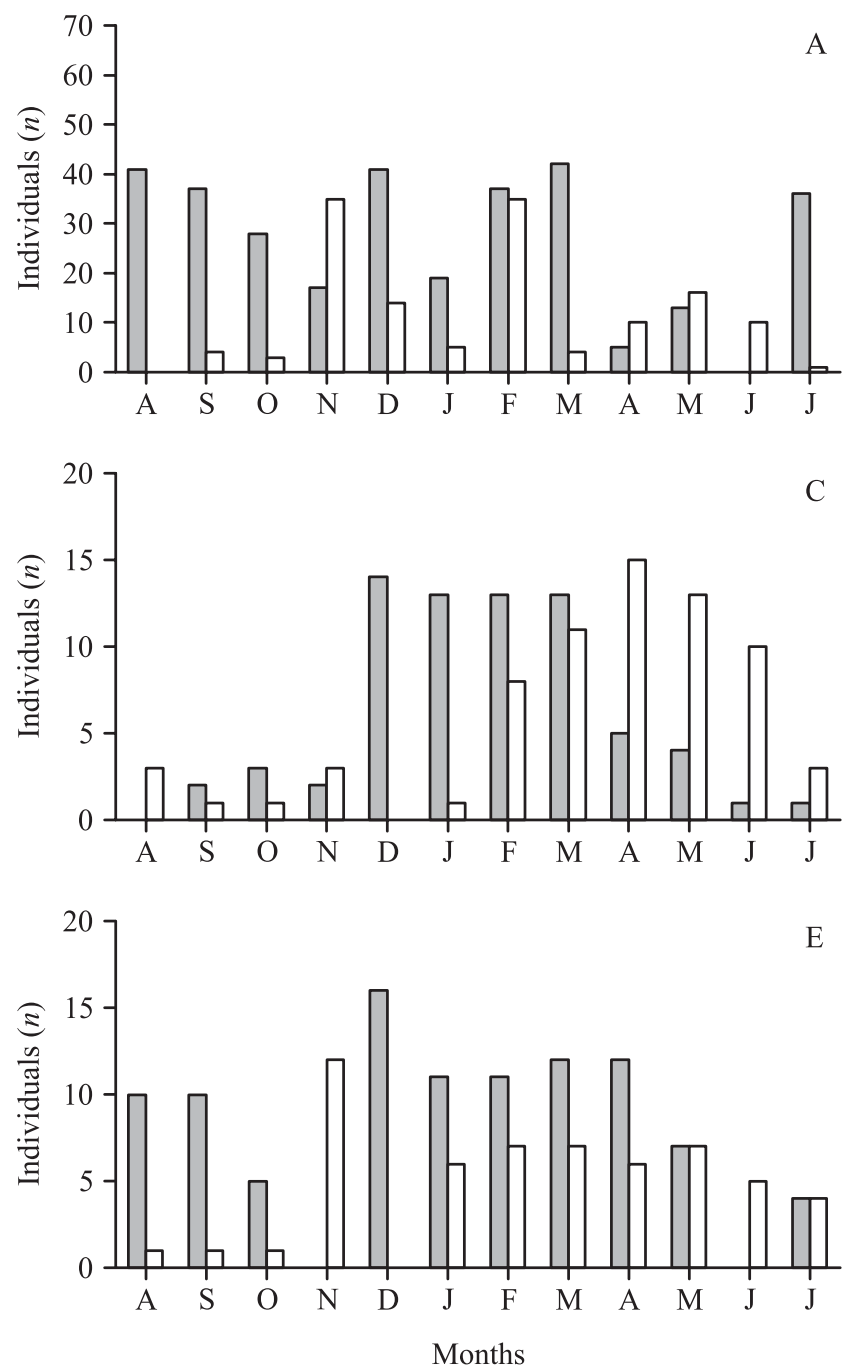

Considering the numbers of flowering and fruiting individuals, $M$. glaucescens, $M$. ernestii, and $M$. $\times$ albicephalus showed a 57\% flowering overlap and a $53 \%$ fruiting overlap. Considering the numbers of flowers and fruits per month, $M$. glaucescens, $M$. ernestii and M. $\times$ albicephalus showed a $45 \%$ flowering overlap and a $38 \%$ fruiting overlap. When pairing up these three species two by two, their flowering overlap was greater than $50 \%$ and their fruiting overlap greater than $40 \%$ (in considering the numbers of individuals demonstrating a given phenophase as well as the quantity of flower and fruit resources offered) (table 1).

Flowering and fruiting in M. paucispinus showed a subannual pattern, with two cycles of intermediate duration ( 2 to 4 months) per year. Flowering peaks took
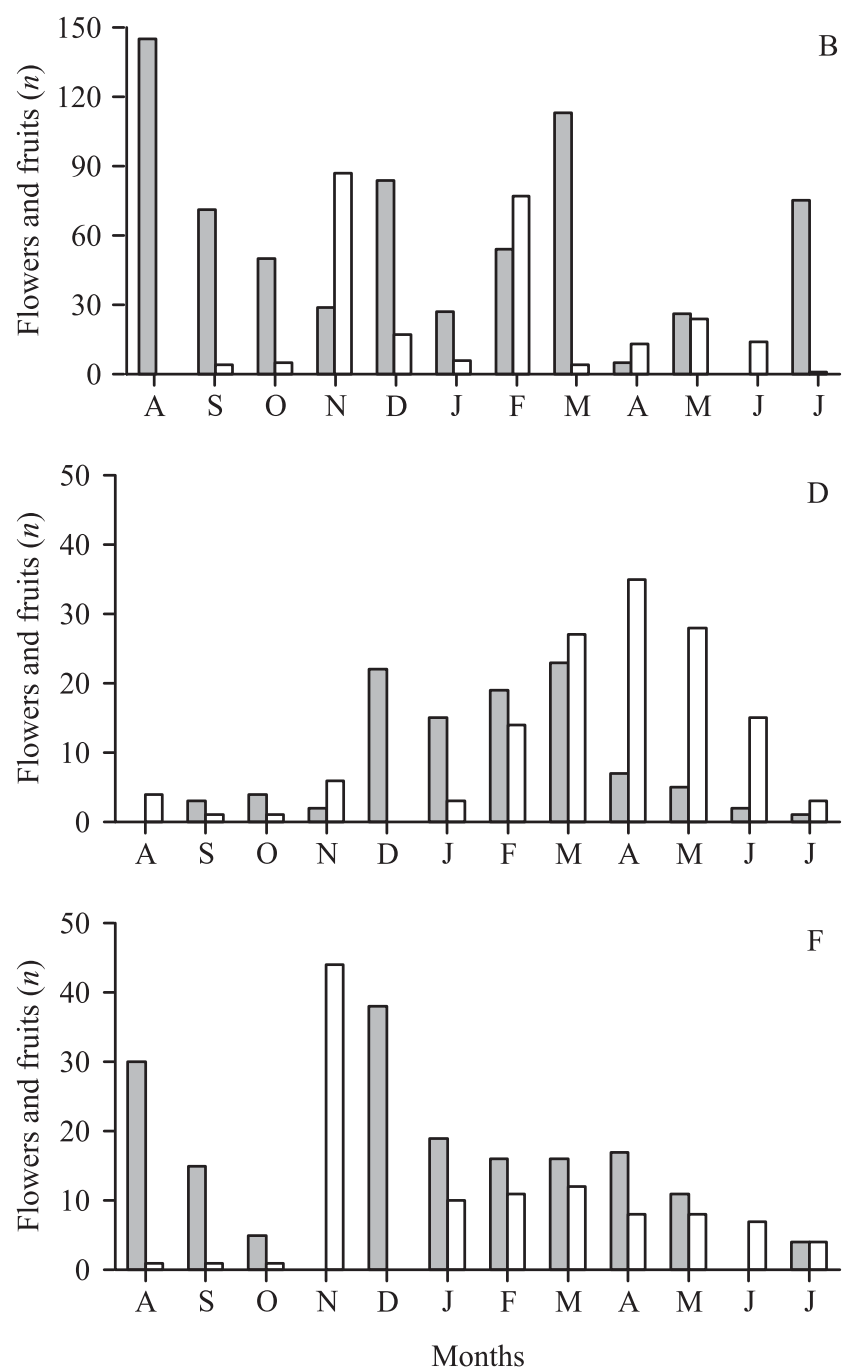

Figure 1. Numbers of flowering $(\square)$ and fruiting $(\square)$ individuals (A, C, E) and total number of flowers $(\square)$ and fruits $(\square)$ $(\mathrm{B}, \mathrm{D}, \mathrm{F})$ of Melocactus glaucescens $(n=70)(\mathrm{A}, \mathrm{B})$, M. ernestii $(n=20)(\mathrm{C}, \mathrm{D})$ and M. $\times$ albicephalus $(n=20)(\mathrm{E}, \mathrm{F})$, recorded during the period from August 2002 to July 2003 in an area of "caatinga"/"cerrado" $22 \mathrm{~km}$ west of the municipal seat of Morro do Chapéu, Bahia State, northeastern Brazil. 
Table 1. Percent overlapping of flowering and fruiting among species of Melocactus of the Chapada Diamantina, Bahia State, Brazil, calculated for all possible pairs of species, and based on the numbers of individuals demonstrating that phenophase and on the numbers of flowers and fruits observed. Based on monthly surveys from 8/2002 to 7/2003.

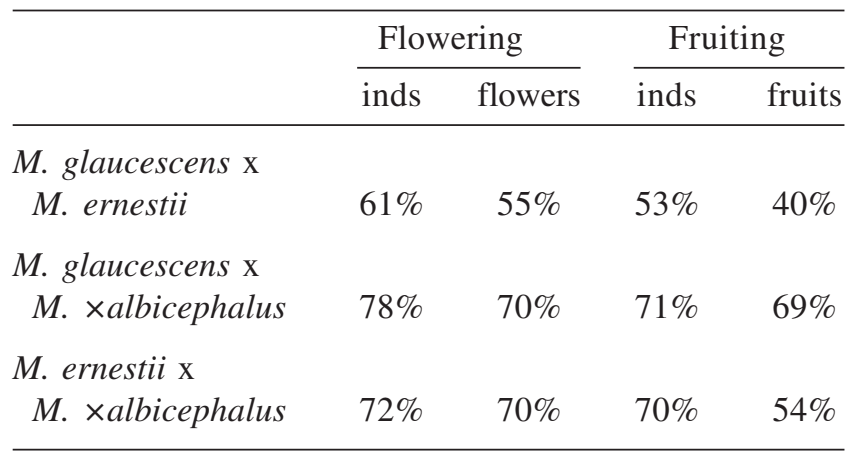

place during dry periods, while fruiting peaks occurred during (or soon after) rainy periods (figure 2). Flowering presented a significant negative correlation with rainfall, and fruiting showed a significant positive correlation with rainfall - but only when considering the number of individuals. Neither humidity nor temperature showed any significant correlation with flowering or fruiting in M. paucispinus, either in terms of number of individuals with flowers or fruits, or the quantity of resources offered (table 2).

Although there were peaks of flowering and fruiting within the taxa of Melocactus studied, it must be stressed that relatively small numbers of flowers and fruits were produced during the whole year.

\section{Discussion}

M. glaucescens and M. ×albicephalus presented similar continuous floral strategies, while $M$. ernestii had an annual pattern of intermediate duration. In spite
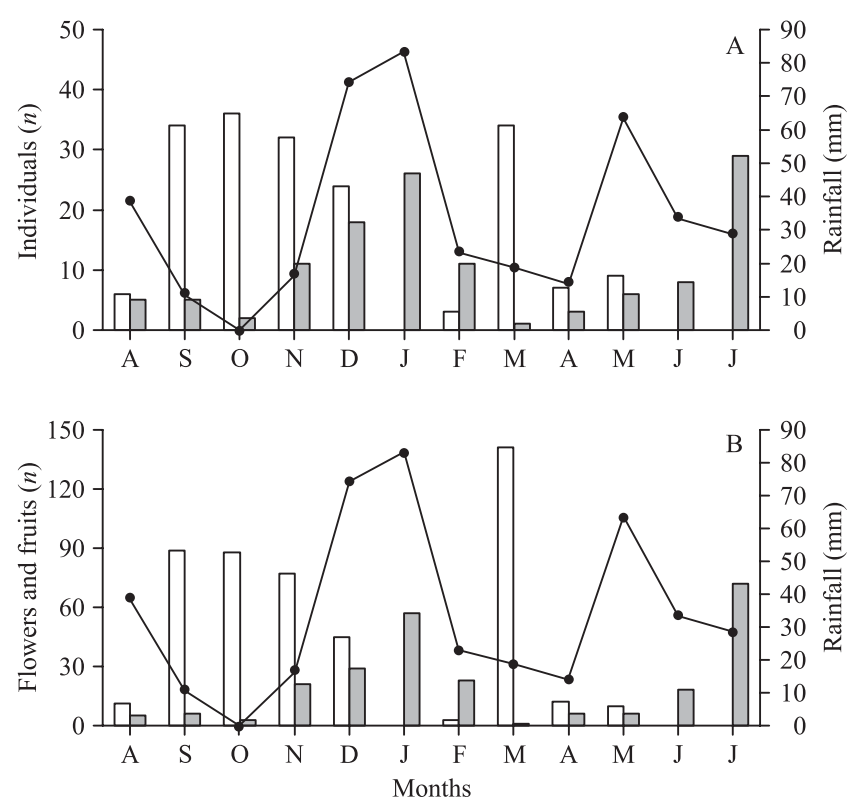

Figure 2. Numbers of flowering ( $\square$ ) and fruiting ( $\square$ ) individuals (A) and total number of flowers $(\square)$ and fruits $(\square)$ (B) of Melocactus paucispinus $(n=50)$ registered during the period from August 2002 to July 2003 in an area of "cerrado"/"campo rupestre" $3 \mathrm{~km}$ west of the municipal seat of Morro do Chapéu, Bahia State, northeastern Brazil.

of these differences, there was considerable overlap of flowering among these three taxa.

Both males and females of Chlorostilbon aureoventris Boucier \& Mulsant (1948) (a hummingbird) are the main pollinators of $M$. glaucescens in the study area, and were also observed visiting individuals of $M$. ernestii and M. ×albicephalus in the study area (Colaço et al. 2006). The degree of flowering overlap observed between $M$. glaucescens and M. ernestii and between these two species and $M . \times$ albicephalus suggests that competition for pollinators may not have been sufficiently strong through the evolutionary history of these populations to establish a separation of their flowering periods.

Table 2. Correlation between the number of individuals of Melocactus paucispinus flowering and fruiting as well as the quantity of flowers and fruits, in terms of the rainfall and the average temperature and humidity, as measured monthly from August 2002 until July, 2003 ( $r_{\mathrm{s}}=$ Spearman's Correlation Coefficient; $P=$ degree of significance).

\begin{tabular}{|c|c|c|c|c|c|c|c|c|}
\hline \multirow{3}{*}{ Environmental variables } & \multicolumn{4}{|c|}{ Flowering } & \multicolumn{4}{|c|}{ Fruiting } \\
\hline & \multicolumn{2}{|c|}{ Individuals } & \multicolumn{2}{|c|}{ Flowers } & \multicolumn{2}{|c|}{ Individuals } & \multicolumn{2}{|c|}{ Fruits } \\
\hline & $r_{\mathrm{s}}$ & $P$ & $r_{\mathrm{s}}$ & $P$ & $r_{\mathrm{s}}$ & $P$ & $r_{\mathrm{s}}$ & $P$ \\
\hline Rainfall & -0.61 & 0.035 & -0.62 & 0.031 & 0.60 & 0.039 & 0.49 & 0.103 \\
\hline Temperature & 0.19 & 0.545 & 0.25 & 0.432 & -0.08 & 0.811 & 0.18 & 0.957 \\
\hline Humidity & -0.49 & 0.102 & -0.44 & 0.151 & 0.07 & 0.824 & 0.03 & 0.930 \\
\hline
\end{tabular}


Long-term flowering (essentially continuous throughout the year in $M$. glaucescens and $M$. $\times$ albicephalus, and for numerous months in M. ernestii) with just a few flowers opening each day can minimize intra- and interspecific competition. This reproductive strategy requires the movement of pollinators between individuals, thus increasing the probability of co-specific cross pollination (Locatelli \& Machado 1999) and consequently increased reproductive success, principally in self-incompatible and allogamic species, as is the case with M. glaucescens (Colaço et al. 2006). This same behavior, however, will also tend to favor hybridization between compatible sympatric species flowering at similar times.

The overlapping flowering phenology reported here supports the hypothesis of hybridization in the study area (Taylor 1991, 2000, Taylor \& Zappi 2004, Lambert et al. 2006b). The flowering strategies of sympatric taxa in the study area do not establish pre-zygotic isolation mechanisms (Stace 1992, Levin 2000); and in addition to allowing for interspecific exchange of genetic material over long periods of time, they favor cross pollination among the taxa.

While $M$. curvispinus demonstrated maximum periods of flowering activity during the rainy season (Nassar \& Ramirez 2004), flowering in M. paucispinus was greater during periods of reduced rainfall. A similar situation to the present study was reported by Locatelli \& Machado (1999) for Melocactus zehntneri. Concentrated flowering during dry periods can be reproductively favorable to a species, for flowers that are vertically positioned on the terminal cephalium in areas of open vegetation can be more easily damaged by heavy rains.

The fruiting peaks of M. paucispinus were associated with rainy periods. Periods with more abundant water resources will favor the production and/or maturation of zoochoric fruits (succulent fruits require more photosynthetic activity and more water for the fruit pulp), and they will also facilitate germination and seedling establishment (Morellato \& Leitão-Filho 1992, 1996). The humidity that accompanies the rainy season, and the temporary abundance of nutrients derived from the decomposition of accumulated leaf litter left from the previous dry season, favor the development of deep root systems before the on set of the next dry season and increase the possibility of survival of the new seedling (van Schaik et al. 1993).

The association of fruiting in M. paucispinus with the rainy season is also beneficial to seed dispersal. Seed dispersion in $M$ paucispinus in the study area is performed by two lizard species (Cnemidophorus ocellifer
Spix, 1825 and Tropidurus cocorobensis Rodrigues, 1987) and four species of ants (Ectatomma edentatum Roger 1863; Acromyrmex laticeps nigrosetosus Forel, 1908; Solenopsis substituta Santschi, 1925, and Dorymyrmex thoracicus Gallardo, 1916) (Fonseca 2004). Fialho (1990) observed a predominance of plant material in the stomach contents of Tropidurus torquatus Wied, 1820 during the rainy season (and a reduced diet of arthropods). On the other hand, Pizo \& Oliveira (2000), in a study of ant-diaspore interactions in the Atlantic Coastal Forest of Brazil noted that diaspores that fall to the ground during periods of high temperatures and frequent rains are subject to more intense harvesting by ant species than at other times during the year. Similar observations were reported by Rico-Gray et al. (1998) in a semi-arid valley in Mexico where ants were less active during the colder and drier parts of the year. Ants tend to be sensitive to environmental humidity, and are less abundant during long dry periods (Levings \& Windsor 1984, Hölldobler \& Wilson 1990). As such, the first fruiting peak of M. paucispinus (November to February) occurs during a rainy and warm period favorable to ant activity; and the second peak of fruiting activity (June and July) coincides with periods of cooler temperatures, but with high humidity and light rainfall.

The continuous (though reduced) production of flowers and fruits observed in the four Melocactus species examined in this study contributes to the maintenance of pollinators (e.g. Chlorostilbon aureoventris) and territorial frugiverous species (e.g. Tropidurus cocorobensis) that use resources provided by these species.

The strategy of offering just a few flowers and fruits a day over long periods of time was also observed in the four Melocactus species examined. The only two other published works with phenological data for the genus (Locatelli \& Machado 1999, Nassar \& Ramirez 2004) described these same phenological strategies, suggesting that they are characteristic of the genus. As such, flowering behavior may be central to explaining the cases of hybridization in various species of Melocactus (Taylor 1991, Taylor \& Zappi 2004, Lambert et al. 2006a, b), while the observed fruiting behavior may be understood as part of an ecological adaptation to saurochory (Figueira et al. 1993, 1994, Taylor 1991, 2000, Fonseca 2004). Additional phenological studies involving other species of Melocactus will be needed to confirm these hypotheses and more precisely define the phenology of this taxon as a whole.

Acknowledgements - The authors would like to thank Marco Aurélio Pizo Ferreira and Roy Funch for improvements to the manuscript, Nigel Taylor and Marlon Machado for 
species identification in the field, and Rubeney Fonseca for aid with the field work. This study was supported by a grant from the Fundo Nacional do Meio Ambiente to E.L. Borba (proc. 75/2001). ELB is supported by a grant (PQ2) from CNPq, and R.B.S. Fonseca received a fellowship from CAPES.

\section{References}

ASHTON, P.S., GIVNISH, T.J. \& APPANAH, S. 1988. Staggered flowering in the Dipterocarpaceae: new insights into floral induction and the evolution of mast fruiting in the aseasonal tropics. American Naturalist 132:44-66.

BERTILLER, M.B., BEESKOW, A.M. \& CORONATO, F. 1991. Seasonal environmental variation and plant phenology in arid Patagonia (Argentina). Journal of Arid Environments 21:1-12.

COLAÇO, M.A.S., FONSECA, R.B.S., LAMBERT, S.M., COSTA, C.B.N. \& BORBA, E.L. 2006. Biologia reprodutiva de Melocactus glaucescens Buining \& Brederoo e Melocactus paucispinus G.Heimen \& R.Paul (Cactaceae), na Chapada Diamantina, Nordeste do Brasil. Revista Brasileira de Botânica 29:239-249.

CPRM. 1995. Projetos mapas municipais - Município de Morro do Chapéu (BA). Ministério de Minas e Energia, Companhia de Pesquisa de Recursos Minerais, Superintendência Regional de Salvador, Salvador.

DNMET. 1992. Normais climatológicas (1961-1990). Departamento Nacional de Meteorologia, Brasília.

FIALHO, R.F. 1990. Seed dispersal by a lizard and a treefrog - Effect of dispersal site on seed survivorship. Biotropica 22:423-424.

FIGUEIRA, J.E.C., VASCONCELLOS-NETO, J., GARCIA, M.A. \& SOUZA, A.L.T. de. 1993. O cactus e o lagarto. Ciência Hoje 15:12-13.

FIGUEIRA, J.E.C., VASCONCELLOS-NETO, J., GARCIA, M.A. \& SOUZA, A.L.T. 1994. Saurocory in Melocactus violaceus (Cactaceae). Biotropica 22:295-301.

FONSECA, R.B.S. 2004. Fenologia reprodutiva e dispersão de Melocactus glaucescens Buining \& Brederoo e $M$. paucispinus G. Heiman \& R. Paul (Cactaceae) no município de Morro do Chapéu, Chapada Diamantina - Bahia - Brasil. Dissertação de mestrado, Universidade Estadual de Feira de Santana, Feira de Santana.

FRANKIE, G.W., BAKER, H. G. \& OPLER, P. 1974. Comparative studies or trees in tropical wet and dry forest in lowlands of Costa Rica. Journal of Ecology 62:881-915.

GENTRY, A.H. 1974. Flowering phenology and diversity in tropical Bignoniaceae. Biotropica 6:48-64.

HÖLLDOBLER, B. \& WILSON, E.O. 1990. The ants. Harvard University Press, Cambridge.

JOHNSON, S.D. 1992. Climatic and phylogenetic determinants of flowering seasonality in the Cape flora. Journal of Ecology 81:567-572.
KOCHMER, J.P. \& HANDEL, S.N. 1986. Constraints and competition in the evolution of flowering phenology. Ecological Monographs 56:303-325.

KREBS, C.J. 1989. Ecological Methodology. Harper \& Row, New York.

LAMBERT, S.M., BORBA, E.L., MACHADO, M.C. \& ANDRADE, S.C.S. 2006a. Allozyme diversity and morphometrics of Melocactus paucispinus (Cactaceae) and evidence for hybridization with $M$. concinnus in the Chapada Diamantina, North-eastern Brazil. Annals of Botany 97:389-403.

LAMBERT, S.M., MACHADO, M.C. \& BORBA, E.L. 2006b. Allozyme diversity and morphometrics of the endangered Melocactus glaucescens (Cactaceae) and investigation of the putative hybrid origin of Melocactus $\times$ albicephalus (Melocactus ernestii $\times$ M. glaucescens) in north-eastern Brazil. Plant Species Biology 21:93-108.

LEVIN, D.A. 2000. The origin, expansion and demise of plant species. Oxford University Press, New York.

LEVIN, D.A., FRANCISCO-ORTEGA, J. \& JANSEN, R.K. 1996. Hybridization and the extinction of rare plants species. Conservation Biology 10:10-16.

LEVINGS, S.C. \& WINDSOR, D.M. 1984. Litter moisture as a determinant of litter arthropod distribution and abundance during the dry season on Barro Colorado Island. Biotropica 16:125-131.

LIETH, H. 1974. Purpose of a phenology book. In Phenology and seasonality modeling (H. Lieth, ed.). Springer Verlag, Berlin, p.3-19.

LOCATELLI, E. \& MACHADO, I.C.S. 1999. Comparative study of the floral biology in two ornithophilous species of Cactaceae: Melocactus zehntneri and Opuntia palmadora. Bradleya 17:75-85.

MACHADO, M.C. 1999. The cacti of Morro do Chapéu, Bahia, Brazil. British Cactus and Succulent Journal 17:201-213.

MACHADO, M.C. \& CHARLES, G. 2004. Pilosocereus bohlei Hofacker a remarkable new species from Brazil. British Cactus and Succulent Journal 22:188-192.

MORELLATO, L.P.C. \& LEITÃO-FILHO, H.F. 1992. Padrões de frutificação e dispersão na Serra do Japi. In História natural da Serra do Japi: Ecologia e preservação de uma área florestal no Sudeste do Brasil (L.P.C. Morellato, ed.). Editora da Unicamp/Fapesp, Campinas, p.112-140.

MORELLATO, L.P.C. \& LEITÃO-FILHO, H.F. 1996. Reproductive phenology of climbers in a Southeastern Brazilian forest. Biotropica 28:180-191.

NASSAR, J.M. \& RAMÍREZ, N. 2004. Reproductive biology of the melon cactus, Melocactus curvispinus (Cactaceae). Plant Systematics and Evolution 248:31-44.

NEWSTROM, L.E., FRANKIE, G.W. \& BAKER, H.G. 1994. A new classification for plant phenology based on flowering patterns in lowland tropical rain forest trees at La Selva, Costa Rica. Biotropica 26:141-159.

NOBEL, P.S. 1977. Water relations of flowering of Agave deserti. Botanical Gazette 138:1-6. 
OLDFIELD, S. 1997. Cactus and Succulent Plants - Status Survey and Conservation Action Plan. IUCN/SSC Cactus and Succulent Specialist Group. União de Conservação Mundial, Gland.

OLLERTON, J. \& LACK, A.J. 1992. Flowering phenology: An example of relaxation of natural selection. Trends in Ecology and Evolution 7:274-276.

PAVÓN, N.P \& BRIONES, O. 2001. Phenological patterns of nine perennial plants in an intertropical semi-arid Mexican scrub. Journal of Arid Environments 49:265-277.

PETIT, S. 2001. The reproductive phenology of three sympatric of columnar cacti on Curaçao. Journal of Arid Environments 49:521-531.

PIZO, M.A. \& OLIVEIRA, P. 2000. The use of fruits and seeds by ants in the Atlantic Forest of southeastern Brazil. Biotropica 32:851-861.

REICH, P.B. 1994. Phenology of tropical forest: patterns, causes and consequences. Canadian Journal of Botany 73:164-174.

REICH, P.B. \& BORCHERT, R. 1984. Water stress and tree phenology in a tropical dry forest in the lowlands of Costa Rica. Journal of Ecology 72:61-74.

RHYMER, J.M. \& SIMBERLOFF, D. 1996. Extinction by hybridization and introgression. Annual Review of Ecology and Systematics 27:83-109.

RICO-GRAY, V., PALACIOS-RIOS, M., GARCIAFRANCO, J.G. \& MACKAY, W.P. 1998. Richness and seasonal variation of ant-plant associations mediated by plant-derived food resources in the semiarid Zapotitlan valley, Mexico. American Midland Naturalist 140:21-26.
SARMIENTO, G. \& MONASTÉRIO, M. 1983. Life forms and phenology. In Ecosystems of the world: tropical savannas (F. Bourlière, ed.). Elsevier, Amsterdam, p. 79-108.

STACE, C. 1992. Plant taxonomy and biosystematics. $2^{\text {nd }}$. ed. Cambridge University Press, Cambridge.

STILES, F.G. 1977. Coadapted pollinators: The flowering seasons of hummingbird-pollinated plants in a tropical forest. Science 198:1177-1178.

TAYLOR, N.P. 1991. The genus Melocactus (Cactaceae) in Central and South America. Bradleya 9:1-80.

TAYLOR, N.P. 2000. Taxonomy and phytogeography of the Cactaceae of Eastern Brazil. PhD thesis, The Open University and Royal Gardens, Kew.

TAYLOR, N.P. \& ZAPPI, D.C. 2004. Cacti of Eastern Brazil. Royal Botanic Gardens, Kew.

VAN SCHAIK, C.P., TERBORGH, J.W. \& WRIGHT, S.J. 1993. The phenology of tropical forests: adaptive significance and consequences for primary consumers. Annual Review of Ecology and Systematics 24: 353-377.

WILliAMS-LINERA, G. \& MEAVE, J. 2002. Patrones fenológicos. In Ecología y conservación de bosques neotropicales (M.R. Guariguata \& G.H. Kattan, eds.). Libro Universitario Regional, Costa Rica, p.407-431.

WRIGHT, S.J. \& CALDERON, O. 1995. Phylogenetic patterns among tropical flowering phenologies. Journal of Ecology 83:937-948.

WRIGHT, S.J. \& VAN SCHAIK, C.P. 1994. Light and the phenology of tropical trees. American Naturalist 143: 192-199. 